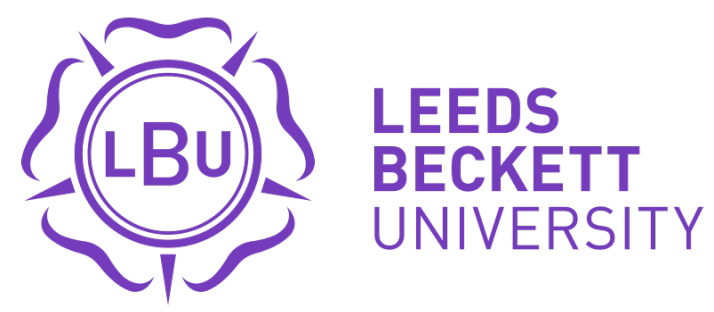

Citation:

Chang, V and Bacigalupo, D and Wills, G and De Roure, D (2010) A categorisation of cloud computing business models. In: CCGrid 2010 - 10th IEEE/ACM International Conference on Cluster, Cloud, and Grid Computing, 2010. UNSPECIFIED, 509 - 512. ISBN 9781424469871 DOI: https://doi.org/10.1109/CCGRID.2010.132

Link to Leeds Beckett Repository record:

https://eprints.leedsbeckett.ac.uk/id/eprint/648/

Document Version:

Book Section (Accepted Version)

The aim of the Leeds Beckett Repository is to provide open access to our research, as required by funder policies and permitted by publishers and copyright law.

The Leeds Beckett repository holds a wide range of publications, each of which has been checked for copyright and the relevant embargo period has been applied by the Research Services team.

We operate on a standard take-down policy. If you are the author or publisher of an output and you would like it removed from the repository, please contact us and we will investigate on a case-by-case basis.

Each thesis in the repository has been cleared where necessary by the author for third party copyright. If you would like a thesis to be removed from the repository or believe there is an issue with copyright, please contact us on openaccess@leedsbeckett.ac.uk and we will investigate on a case-by-case basis. 


\title{
A Categorisation of Cloud Computing Business Models
}

\author{
Victor Chang, David Bacigalupo, Gary Wills, David De Roure \\ School of Electronics and Computer Science, University of Southampton, \\ Southampton SO17 1BJ. United Kingdom \\ vic1e09@ecs.soton.ac.uk
}

\begin{abstract}
This paper reviews current cloud computing business models and presents proposals on how organisations can achieve sustainability by adopting appropriate models. We classify cloud computing business models into eight types: (1) Service Provider and Service Orientation; (2) Support and Services Contracts; (3) In-House Private Clouds; (4) All-In-One Enterprise Cloud; (5) One-Stop Resources and Services; (6) Government funding; (7) Venture Capitals; and (8) Entertainment and Social Networking. Using the Jericho Forum's 'Cloud Cube Model' (CCM), the paper presents a summary of the eight business models. We discuss how the CCM fits into each business model, and then based on this discuss each business model's strengths and weaknesses. We hope adopting an appropriate cloud computing business model will help organisations investing in this technology to stand firm in the economic downturn.
\end{abstract}

\section{INTRODUCTION}

Cloud Computing aims to provide scalable and inexpensive on-demand computing infrastructures with good quality of service (QoS) levels. More specifically, this involves a set of network-enabled services that can be accessed in a simple and pervasive way [10]. Cloud Computing provides a compelling value proposition for organisations to outsource their Information and Communications Technology (ICT) infrastructures [6]. It also provides added value for organisations; saving costs in operations, resources and staff - as well as new business opportunities for service-oriented models [2, $3,10]$. In addition, it is likely cloud computing focusing on operational savings and green technology will be at the centre of attention. To avoid repeats of Internet bubbles and to maintain business operations, achieving long-term sustainability is an important success factor for organisations [4]. In this paper we review current cloud computing business models, and provide recommendations on how organisations can achieve sustainability by adopting appropriate models.

\section{BUSINESS MODEL CLASSIFICATION}

Extensive work has been done on investigating business models empowered by Cloud technologies [9]. Despite leading IT vendors such as Amazon, Microsoft, Google, IBM and Salesforce taking the lead, the amount of investment and spending is still more than the profits received from these investments. This illustrates the importance of classifying the right business strategies and models for long-term sustainability. Based on previously identified use cases, surveys, analysis and reviews of cloud computing business models $[1,4,5,8]$, we categorise these models into eight types: (1) Service Provider and Service Orientation; (2) Support and Services Contracts; (3) In-House Private Clouds; (4) AllIn-One Enterprise Cloud; (5) One-Stop Resources and Services; (6) Government funding; (7) Venture capitals and (8) Entertainment and Social Networking.

\section{THE CLOUD CUBE MODEL AND OUR UPDATED DEFINITIONS}

The Cloud Cube Model (CCM) proposed by The Jericho Forum (JF) is used to enable secure collaboration in the appropriate cloud formations best suited to the business needs [7]. The JF points out that many cloud service providers claim themselves to be able to deliver solutions, so cloud customers need selecting the right formation within CCM suiting their needs. Within CCM, four distinct dimensions are identified. They are (a) External and Internal; (b) Proprietary and Open; (c) Perimeterised (Per) and De-Perimeterised (D-p), and (d) In-sourced and Outsourced. Section 3.1 to 3.4 describes how each component fits the business models. The Diagram for CCM is in Figure 1 [7].

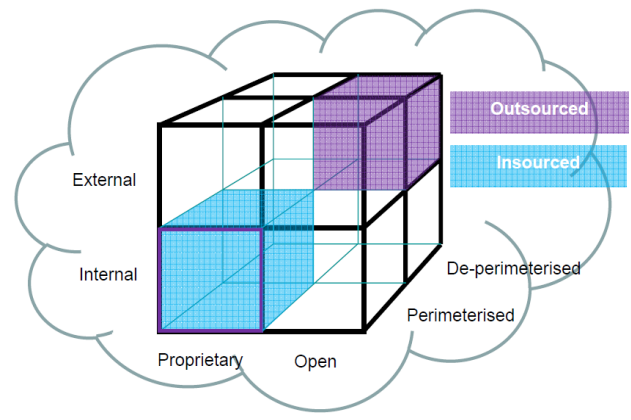

Figure 1: The Cloud Cube Model

\subsection{Internal and External}

This dimension describes the type of business model to go for. Internal means private clouds and External means public clouds.

\subsection{Proprietary and Open}

Proprietary means paid services or contractors. Open stands for open source services or solutions. In the context of cloud computing, sometimes open means a system or platform that allows sharing and free accessing of APIs, and in this respect, Google App Engine can be considered as open. 


\subsection{Perimeterised (Per) and De-perimeterised (D-p)}

The original definition refers to $P e r$ and $d-p$ as an architectural mindset - that is, whether traditional IT perimeters such as network and firewall are operating inside (Per) or outside (D-p) the organisation. In our context different from JF, perimeterised means infrastructure as a service (IaaS) and platform as a service (PaaS), or any services, contracts and supports using infrastructure and platform. De-perimeterised stands for Software as a Service (SaaS), or any services, contracts or supports for software/application, since they are restricted by hardware boundary.

\subsection{Insourced and Outsourced}

Insourced means in-house development of clouds. Outsourced refers to letting contractors or service providers handle all requests, and most of cloud business models fall into this.

\section{HOW EACH BUSINESS MODEL FIT INTO THE $\mathrm{CCM}$}

In this Section, how each business model fits into the Cloud Cube Model is explained. Strengths and weaknesses for each business model are also presented at the end of each sub section.

\subsection{Service Provider and Service Orientation}

Most Service Providers offer public clouds, which include infrastructure, platform and software as a service. Service Providers require clients to outsource to them. Therefore, this business model takes on all the upper part of the Cloud Cube Model (CCM) in light purple colour, shown in Figure 2.

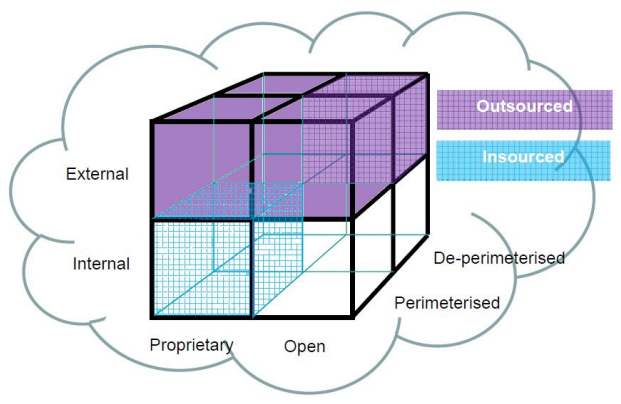

Figure 2: CCM for Service Providers and Service Orientation

\begin{tabular}{|l|l|}
\hline \multicolumn{1}{|c|}{ Strength } & \multicolumn{1}{|c|}{ Weakness } \\
\hline $\begin{array}{l}\text { This is a main stream } \\
\text { business model, and } \\
\text { demands and requests are } \\
\text { guaranteed. }\end{array}$ & $\begin{array}{l}\text { Competitions can be very } \\
\text { stiff in an all of } \\
\text { and software as a service. }\end{array}$ \\
$\begin{array}{l}\text { There are still unexploited } \\
\text { areas for offering services } \\
\text { and making profits. }\end{array}$ & $\begin{array}{l}\text { Data privacy is a concern } \\
\text { for some clients. }\end{array}$ \\
\hline
\end{tabular}

Service providers in Infrastructure as a Service (IaaS), Platform as a Service (PaaS) and Software as a Service (SaaS) all fall into this model.

\subsection{Support and Service Contracts}

Support and Service Contractors deal in proprietary solutions for private domains, and they can cover infrastructure, platform and software services. Therefore, this model occupies the lower-left front and back of the Cloud Cube Model coloured in the light purple shown in Figure 3 below.

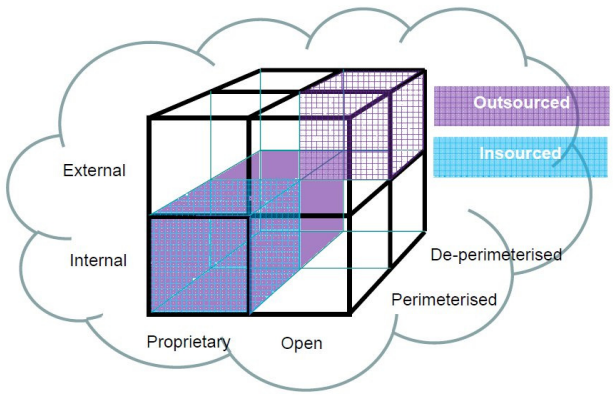

Figure 3: CCM for Support and Service Contracts

\begin{tabular}{|l|l|}
\hline \multicolumn{1}{|c|}{ Strength } & \multicolumn{1}{|c|}{ Weakness } \\
\hline $\begin{array}{l}\text { Suitable for small and } \\
\text { medium enterprises who }\end{array}$ & Some firms may \\
experience a period \\
can make extra profits \\
without contracts, and \\
of services. & $\begin{array}{l}\text { they must change their } \\
\text { strategies. }\end{array}$ \\
\hline
\end{tabular}

\subsection{In-House Private Clouds}

The In-House Private Cloud model deals with private clouds, and does not seek outsourcing. This model can work for Software as a Service. Early starters for such projects currently focus on infrastructure and platform levels. Therefore, the In-House Private Cloud model takes the lower front quarter of CCM, coloured in light blue colour, shown in Figure 4.

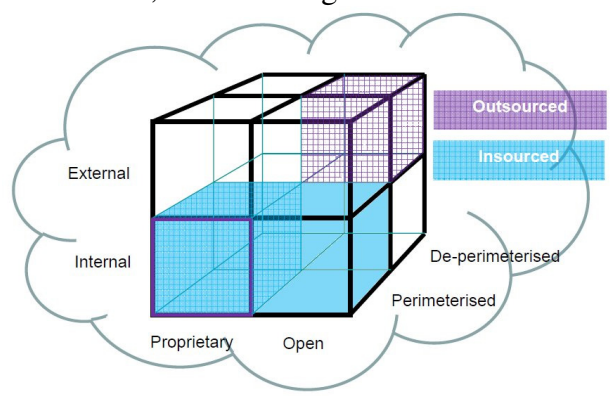

Figure 4: CCM for In-House Private Clouds

\begin{tabular}{|c|c|}
\hline Strength & Weakness \\
\hline $\begin{array}{l}\text { Best suited } \\
\text { organisations der } \\
\text { their own private clouds } \\
\text { which will not have data } \\
\text { security and data loss } \\
\text { concerns. }\end{array}$ & $\begin{array}{l}\text { Projects can be } \\
\text { complicated and time } \\
\text { consuming. }\end{array}$ \\
\hline
\end{tabular}




\subsection{All-In-One Enterprise Cloud}

The All-In-One Enterprise Cloud model takes on all parts of the CCM, and has the combined characteristics of Service Provider and Orientation model and the ideal In-House Private Clouds model. The only difference is that there are areas overlapped with both outsourced and in-house options, which is introduced as a dark purple colour. Therefore, all parts of CCM are in light purple colours except for internal clouds, which has joint characteristic of outsourcing and in-house development and is in dark purple colour as shown in Figure 5 below.

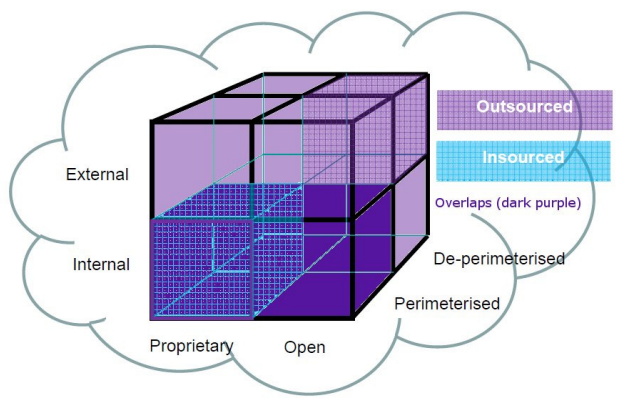

Figure 5: CCM for All-In-One Enterprise Cloud

\begin{tabular}{|l|l|}
\hline \multicolumn{1}{|c|}{ Strength } & \multicolumn{1}{|c|}{ Weakness } \\
\hline $\begin{array}{l}\text { Can be the ultimate } \\
\text { business model for big } \\
\text { players }\end{array}$ & $\begin{array}{l}\text { Small and medium } \\
\text { enterprises are likely not to } \\
\text { be suitable for this, unless } \\
\text { they join part of an }\end{array}$ \\
$\begin{array}{l}\text { Consolidating different } \\
\text { ecosystem. } \\
\text { business activities and } \\
\text { strategies, including an } \\
\text { ecosystem approach or } \\
\text { comprehensive SaaS. }\end{array}$ \\
\hline
\end{tabular}

\subsection{One-Stop Resources and Services}

The One-Stop Resources and Services model has the same characteristics as Service Provider and Orientation model, except this model often needs combined effort from both outsourced and in-housed effort. Currently proprietary vendors are taking a lead compared to academic community clouds. Even if a community cloud exists, it must be on a public domain for restricted users only, and in that respect, they are in external rather than internal cloud. This model takes on upper half of CCM in dark purple as shown in Figure 6.

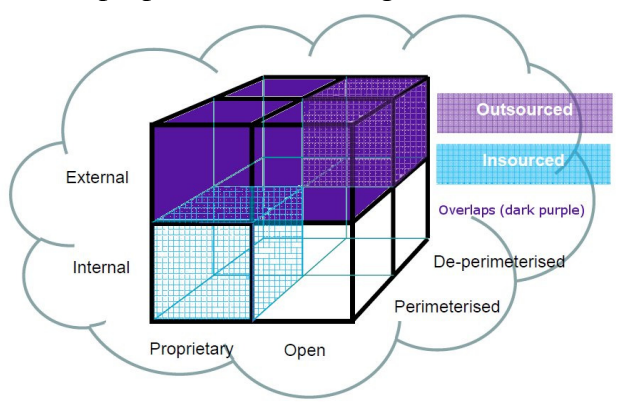

Figure 6: CCM for One-Stop Resources and Services

\begin{tabular}{|l|l|}
\hline \multicolumn{1}{|c|}{ Strength } & \multicolumn{1}{|c|}{ Weakness } \\
\hline $\begin{array}{l}\text { A suitable model for } \\
\text { business partnership and } \\
\text { academic community. }\end{array}$ & $\begin{array}{l}\text { All participating } \\
\text { organisations or members } \\
\text { should contribute. If not } \\
\text { Can get mutual benefits } \\
\text { managed well, it may end }\end{array}$ \\
through collaboration. & $\begin{array}{l}\text { up in other business } \\
\text { models or a community } \\
\text { breaking apart. }\end{array}$ \\
\hline
\end{tabular}

\subsection{Government Funding}

Government funds are available for both academic institutions and corporate firms. However, the funding purpose and research directions for both groups are often not the same. If government is funding private sectors, it is considered as outsourcing, and is taking left-half of the CCM model in light purple. When the government is funding academic institutions, which requires a period for internal research and development (R\&D) work, thus they take on right half of the CCM in light blue. Government then looks at two sides of research outcomes, and would like to find a joint solution, or hybrid recommendation, and therefore both solutions overlap in the middle with dark purple colour as shown in Figure 7.

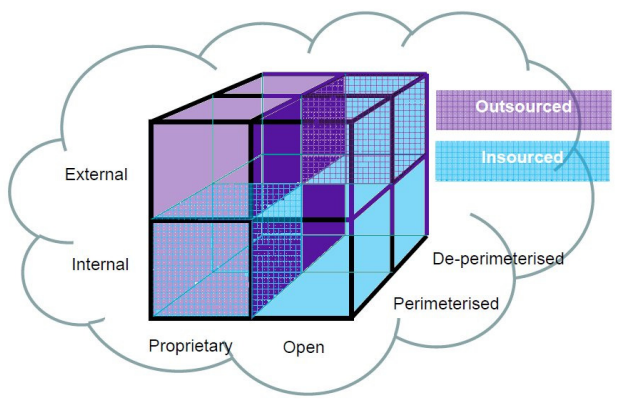

Figure 7: CCM for Government Funding

\begin{tabular}{|c|c|}
\hline Strength & Weakness \\
\hline $\begin{array}{l}\text { Government can invest a } \\
\text { massive amount, and } \\
\text { this is beneficial for } \\
\text { projects requiring } \\
\text { extensive } \\
\text { resources and highly } \\
\text { trained staff. }\end{array}$ & $\begin{array}{l}\text { Only affluent governments } \\
\text { can afford that, and also } \\
\text { top-class firms and } \\
\text { universities tend to be } \\
\text { selected. }\end{array}$ \\
\hline
\end{tabular}

\subsection{Venture Capital}

Venture capital has a similar approach as Government funding, except the open, de-perimeterised and external cloud within CCM is not just an in-housed approach but an integrated approach. This is because investors tend to think if a successful cloud project is not only relevant to their invested firms, but also if it is appealing to a wider group of users - with examples such as Ubuntu and Parascale. Hence, there are more overlapped areas than government funding model, including the right upper quarter of CCM. These external clouds can be outsourced (Ubuntu and Amazon EC2; or Ubuntu support/services) or in-housed (users can opt for Ubuntu 
Private clouds). The remaining area in the right lower quarter is in light blue due to in-house research and development. Figure 8 below is the best representation for Venture capital model.

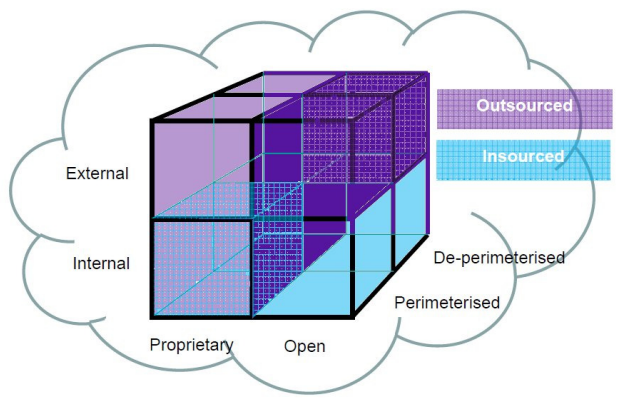

Figure 8: CCM for Venture capital

\begin{tabular}{|l|lr|}
\hline \multicolumn{2}{|c|}{ Strength } & \multicolumn{2}{|c|}{ Weakness } \\
\hline Can receive a surplus that & It can be a prolonged \\
is essential for & process without a \\
sustainability. Useful for & guarantee to get \\
start-ups, or organisations & anything. \\
nearly running out of cash. & \multicolumn{2}{|}{} \\
\hline
\end{tabular}

\subsection{Entertainment and Social Networking}

Currently Entertainment and Social Networking focus on Software as a Service, and are typically proprietary and outsourced solutions. Therefore, it only occupies one cube (in light purple) within the Cloud Cube Model. Despite this, this model has the largest number of users, which boosts its services, advertising and peripheral product sales. Profits/investment attracted by Apple, Facebook and Shanda Games are very large given the age of these companies. See Figure 9 below.

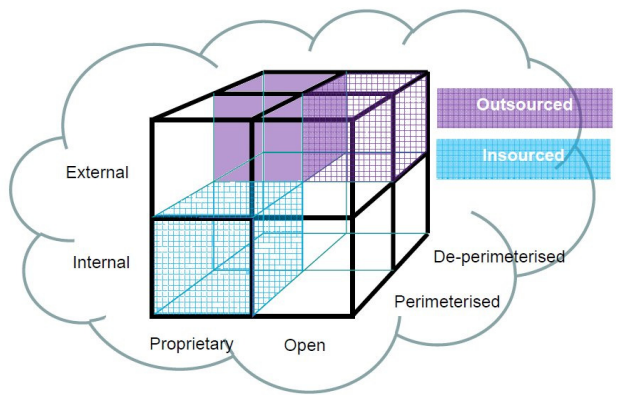

Figure 9: CCM for Entertainment and Social Networking

\begin{tabular}{|l|l|}
\hline \multicolumn{1}{|c|}{ Strength } & \multicolumn{1}{|c|}{ Weakness } \\
\hline $\begin{array}{l}\text { If successful, this model } \\
\text { tends to dash into a } \\
\text { storm of popularity and } \\
\text { money in a short time. }\end{array}$ & $\begin{array}{l}\text { Peential social problems. } \\
\text { social networking and } \\
\text { excessive gaming, not } \\
\text { attending school and bad } \\
\text { social behaviour in a few } \\
\text { extreme cases. }\end{array}$ \\
\hline
\end{tabular}

\section{CONCLUSION}

Cloud computing business models are a relatively new area, and finding the right business models can enhance organisational sustainability. In this paper, we classify cloud computing business models into eight types. We discuss how the Cloud Cube Model (CCM) fits into each business model. Based on this we discuss the strengths and weaknesses of each business model. By adopting the right business model, we hope organisations can stand firm in economic downturns and expand their businesses.

Future work includes publishing details of our proposed Financial Cloud Framework (FCF). This extends our business models and CCM with a focus on the healthcare and financial domains, and includes financial modelling in forecasting, modelling, simulations and benchmarking of financial assets. An objective for FCF is to simplify business models and processes. Currently a small number of organisations have either adopted or are considering using our cloud computing business models and the FCF. These include an anonymous NHS entity in London and an anonymous University working together for private clouds, and the UK National Grid Service and the OMII-UK for community and hybrid clouds. We will propose another new business model, the Hexagon Model, and will explain how it can complement with the CCM with more case studies and modelling presented.

\section{REFERENCES}

[1] Armbrust M et al, "Above the Clouds: A Berkeley View of Cloud Computing”, UC Berkeley Reliable Adaptive Distributed Systems Laboratory Technical Report, February 2009.

[2] Boss G et al, "Cloud Computing", IBM white paper, Version 1.0, October 2007.

[3] Chang V., et al "Cancer Cloud Computing - Towards an Integrated Technology Platform for Breast Cancer Research", NHS Technical Paper, July 2009.

[4] Chang V, Mills, H. and Newhouse, S. (2007) "From Open Source to long-term sustainability: Review of Business Models and Case studies". UK e-Science All Hands Meeting, Nottingham, UK, September 2007

[5] Chang V, "The Financial Cloud Computing", nine-month thesis technical report, University of Southampton School of Electronics and Computer Science, February 2010.

[6] Haynie M, "Enterprise cloud services: Deriving business value from Cloud Computing," Micro Focus, Technical Report, 2009.

[7] Jericho Forum, "Cloud Cube Model: Selecting Cloud Formations for Secure Collaboration Version 1.0", Jericho Forum Specification, April 2009.

[8] Lazonick W, "Evolution of the New Economy Business Model", UMass Lowell and INSEAD, 2005.

[9] Lohr S, "Google and I.B.M. Join in 'Cloud Computing' Research", New York Times, October 2007

[10] Wang L, Kunze M et al, "Cloud Computing: a Perspective Study", Grid Computing Environments Workshop (GCE'08), Austin, Texas, December 2008 